\title{
Effect of Farmyard Manure, Lime and Inorganic Fertilizer Applications on Soil pH, Nutrients Uptake, Growth and Nodulation of Soybean in Acid Soils of Western Kenya
}

\author{
Hillary M. O. Otieno ${ }^{1}$, George N. Chemining' wa ${ }^{1} \&$ Shamie Zingore ${ }^{2}$ \\ ${ }^{1}$ Department of Plant Science and Crop Protection, University of Nairobi, Nairobi, Kenya \\ ${ }^{2}$ International Plant Nutrition Institute, Sub-Saharan Africa Program, Nairobi, Kenya \\ Correspondence: Hillary M. O. Otieno, Department of Plant Science and Crop Protection, University of Nairobi, \\ Nairobi, Kenya. Tel: 254-729-357-329. E-mail: hillarymoses.otieno@gmail.com
}

Received: January 2, 2017

doi:10.5539/jas.v10n4p199

\begin{abstract}
Soybean is an important crop with nutrition, economic and soil fertility improvement benefits to farmers. However, its production in western Kenya is partly constrained by low soil $\mathrm{pH}$ and soil fertility levels. A greenhouse pot study was conducted to evaluate the effects of inorganic fertilizers, farmyard manure and lime application on soil $\mathrm{pH}$, nutrient uptake, growth and nodulation of soybean grown in acidic soils from western Kenya. The experiment was set up in a randomized complete block design with eight treatments: control; NPK; manure; lime; manure+lime; NPK+manure; NPK+lime and manure+lime+NPK. Significant effects of inorganic fertilizers, manure and lime applications were observed on all the variables. Manure, lime and manure+lime treatments increased soil $\mathrm{pH}$ by $1.33,2.19$ and 2.28 , respectively, above the control treatment. The shoot $\mathrm{N}$ was lower under control (1.71-1.81\%), NPK (1.85-1.98\%) and manure (2.00-2.11\%) than under all other treatments. Treatments NPK+lime and manure+lime+NPK recorded higher uptake of $\mathrm{P}$ and $\mathrm{K}$ nutrients than all other treatments. The control and NPK treatments recorded shorter plants and low leaf area and above-ground biomass compared to other treatments. The NPK+lime and manure+lime+NPK treatments recorded higher plant height and aboveground biomass than other treatments. Lime+manure treatment recorded highest nodule numbers and dry weights per plant. Positive relationships were observed between $\mathrm{pH}$ and $\mathrm{N}, \mathrm{P}$ and $\mathrm{K}$ nutrient uptake $\left(\mathrm{R}^{2}\right.$ ranged between 0.30 and 0.77 ) and between biomass and $\mathrm{N}, \mathrm{P}$ and $\mathrm{K}$ nutrient uptake $\left(\mathrm{R}^{2}\right.$ ranged between 0.68 and 0.99 ). From this study, use of manure and lime could result in improved soil $\mathrm{pH}$ for better uptake of nutrients, nodule formation and productivity of soybean in Western Kenya.
\end{abstract}

Keywords: fertilizer application, nutrient uptake, lime application, manure application, soil $\mathrm{pH}$, soybean growth

\section{Introduction}

Soybean (Glycine max) is a minor crop in Kenya mainly grown in few regions; Busia, Bungoma, Rachuonyo, Homa Bay, Kirinyaga and Murang'a (Chianu et al., 2008). The current annual production stands at 2550 metric tons (FAOSTAT, 2014). Soybean is nutritionally rich with $40 \%$ protein, $21 \%$ oil and $34 \%$ carbohydrates expressed in over 39 soybean-based products found across the country. Intercropping or rotating soybean with cereals such as maize has also been reported to increase their productivity by approximately $25 \%$ due to the symbiotic nitrogen fixation ranging between 44 and $103 \mathrm{~kg} \mathrm{~N} / \mathrm{ha}$ annually (Chianu \& Vanlauwe, 2006). Under such cropping systems, soybean also helps in controlling parasitic weeds such as Striga hermontheca (Adelodun, 2011). Despite these benefits, soybean productivity is still low ranging 0.6-1.4 t/ha compared to its potential yield of 3.6 t/ha (Chianu \& Vanlauwe, 2006; Verde at al., 2013; FAOSTAT, 2014). Such low productivity is partly associated with soil infertility and low soil $\mathrm{pH}$ levels experienced across the major soybean producing regions of Kenya (Mbakaya, 2007). Soil pH levels reported in western Kenya ranges from 3.8 to 5.5 (Kanyanjua et al., 2002; Owino et al., 2015) due to high levels of aluminium and iron cations (Kisinyo et al., 2012). Such high acidity has been cited to be the main cause of high $\mathrm{P}$ adsorption and unavailability of other nutrients in the soil leading to poor crop growth and productivity in these regions (Gudu et al., 2009). Low pH and high aluminum concentration severely affect rhizobia and other soil fauna responsible for improving soil health (Johnson \& Wood, 1990). 
Application of lime and manure is effective in cushioning soil $\mathrm{pH}$ to levels suitable for crop production. The calcium and magnesium ions in lime, apart from displacing hydrogen, aluminum and iron ions from the soil colloids thereby raising $\mathrm{pH}$, provide soybean with available $\mathrm{Ca}$ and $\mathrm{Mg}$ nutrients for growth and productivity (Onwonga et al., 2010; Kisinyo et al., 2012). Manure on the other hand releases nutrients for growth and at the same time form complexes with aluminum and iron ions thereby reducing their adverse effects on soybean growth (Haynes \& Mokolobate, 2001; Fatondji et al., 2009). Application of inorganic fertilizers offer immediate corrective measure to nutrient deficiencies by supplying critically required nutrients in their correct forms for plant use. However, use of such nutrient sources and crop residue incorporation as soil amendments to improve soybean productivity is not commonly practiced in western Kenya due to poverty and alternative competitive uses of crop residues and manure, for example as building materials, fuel and animal feed. In addition, animal manure only benefits home fields as farmers do not take these materials to fields away from the homestead due to distance and bulkiness. In case of farmers who can afford to supply some quantities of fertilizer, the nutrients are likely to be used with high inefficiencies due to high soil acidity resulting in low soybean production. Therefore, this study was conducted to determine the effect of applying manure, lime and inorganic fertilizers on soil $\mathrm{pH}$, and nutrient uptake, growth and nodulation of soybean grown in acid soils from western Kenya region.

\section{Materials and Methods}

\subsection{Site Description}

A greenhouse pot experiment was conducted at the College of Agriculture and Veterinary Sciences, University of Nairobi, located on latitude $1^{\circ} 15^{\prime}$ South and longitude $36^{\circ} 44^{\prime}$ East. The area has an altitude of $1800 \mathrm{~m}$ above sea level with an average temperature of $21{ }^{\circ} \mathrm{C}$. Soil samples were collected from Masaba and Eshirali locations in Butere Sub-county, Kakamega County, Kenya and analyzed for pH, total N, P and K. Kakamega County has a mean temperature of $26{ }^{\circ} \mathrm{C}$ and receives an annual average rainfall of $1947 \mathrm{~mm}$ that occurs twice a year; long rains between March and July and short rains between October and December. Masaba soils had a $\mathrm{pH}$ of 4.1, $0.13 \% \mathrm{~N}, 5.67 \mathrm{ppm} \mathrm{P}$ and $1.01 \mathrm{Cmol} / \mathrm{kg} \mathrm{K}$ while Eshirali site had a pH of 4.8, $0.21 \% \mathrm{~N}, 7 \mathrm{ppm} \mathrm{P}$ and 0.37 $\mathrm{Cmol} / \mathrm{kg}$.

\subsection{Soil Sampling, Experimental Design and Treatments}

Soil samples were collected at a depth of 0-20 cm in each study site (after surface debris was cleared) using the transverse method. These samples were then bulked, dried, thoroughly under shade, mixed then screened through $0.5 \mathrm{~cm}$ screen to maintain the soil physical properties and to avoid compaction in the pots during the experiment. Equal amounts of soils in $5 \mathrm{~kg}$ capacity pots of conical shape were then used for planting of soybean. The experiment was set up in a randomized complete block design with eight treatments (control; NPK; manure; lime; manure+lime; NPK+manure; NPK+lime and manure+lime+NPK) that were replicated four times. The N, P and $\mathrm{K}$ nutrients were applied at the rates of 20,30 and $60 \mathrm{~kg} / \mathrm{ha}$ from urea, triple superphosphate and muriate of potash, respectively. Lime and manure were applied at the rate of 5 and $10 \mathrm{t} / \mathrm{ha}$ using dolomite and cattle manure source, respectively. Nitrogen was applied in two splits $-10 \mathrm{~kg} / \mathrm{ha}$ at planting and the remaining $10 \mathrm{~kg} / \mathrm{ha}$ as top-dress at 25 days after planting. All triple superphosphate, muriate of potash, lime and manure were applied at planting. The treatments were thoroughly mixed with soil then put in the pots. The pots were arranged in a perpendicular position to the path of the sun on metallic tables in a greenhouse.

\subsection{Agronomic Practices}

Certified soybean SB 132 variety seeds were obtained from CIAT Centre at Maseno. Two seeds were planted in every pot at about $4 \mathrm{~cm}$ deep then covered uniformly. After emergence, the seedlings were thinned to one per plot. Each pot was put on a wide plate to prevent leakage of applied nutrients and water. Throughout the growing season, the plants were watered uniformly to maintain soil moisture as close as possible to the field capacity so that growth was not limited by water stress. The pots were also kept weed free by hand-pulling of weeds as soon as they emerged. The incidences of pest and diseases were also monitored throughout the growth period.

\subsection{Data Collection}

Data was collected at the termination stage of the experiment (flower initiation stage). The parameters considered were the plant leaf area, plant height, number of nodules per plant, nodule dry weight per plant and aboveground biomass. Soil $\mathrm{pH}$ and plant nutrient uptake were also analyzed.

Leaf area: Leaf area was calculated by tracing leaf outlines on $1 \mathrm{~mm}^{2}$ graph paper.

Plant height: Soybean height was determined by taking an average of four plants using a meter rule. 
Nodulation: Number of nodules per plant was given by the average number of the nodules from all the four replicates. During the process, each plant pot was emptied in a bucket of flowing water to wash off the soil on the roots. The nodules were manually counted then dried at $65^{\circ} \mathrm{C}$ in an oven to a constant dry weight.

Aboveground biomass: Biomass production from each treatment was computed from the average of four plants cut above the soil level, weighed (fresh weights) then dried at $65^{\circ} \mathrm{C}$ to a constant dry weight (dry matter).

Soil $\mathrm{pH}$ : The soil $\mathrm{pH}$ (water) was determined at the end of the experiment using six grams subsamples from air-dried, crushed and sieved soils from each pot.

Nutrient uptake: Leaves were sampled, dried at $65{ }^{\circ} \mathrm{C}$ for 24 hours, ground to fine powder and analyzed for total $\mathrm{N}, \mathrm{P}$, and $\mathrm{K}$. The Kjeldahl procedure was used for tissue analysis to determine total N (Bremner \& Mulvaney, 1982). Foliar P and K nutrients were determined using spectrophotometry and flame photometry procedures, respectively (Page et al., 1982).

\subsection{Data Analysis}

Data obtained was subjected to analysis of variance using GenStat $15^{\text {th }}$ Edition software. Fisher's protected least significant difference test (5\%) was applied to separate treatment means. A simple excel linear analysis was also conducted to show the relationship between $\mathrm{pH}$ and uptake of nutrients and between biomass and uptake of nutrients.

\section{Results}

\subsection{Effect of Manure and Lime Application on Soil pH}

Manure, lime and manure+lime application significantly $(\mathrm{p}<0.05)$ increased soil $\mathrm{pH}$ by $1.24,1.89$ and 1.96 (Eshirali soil) and 1.42, 2.48 and 2.59 (Masaba soil) respectively (Figure 1).
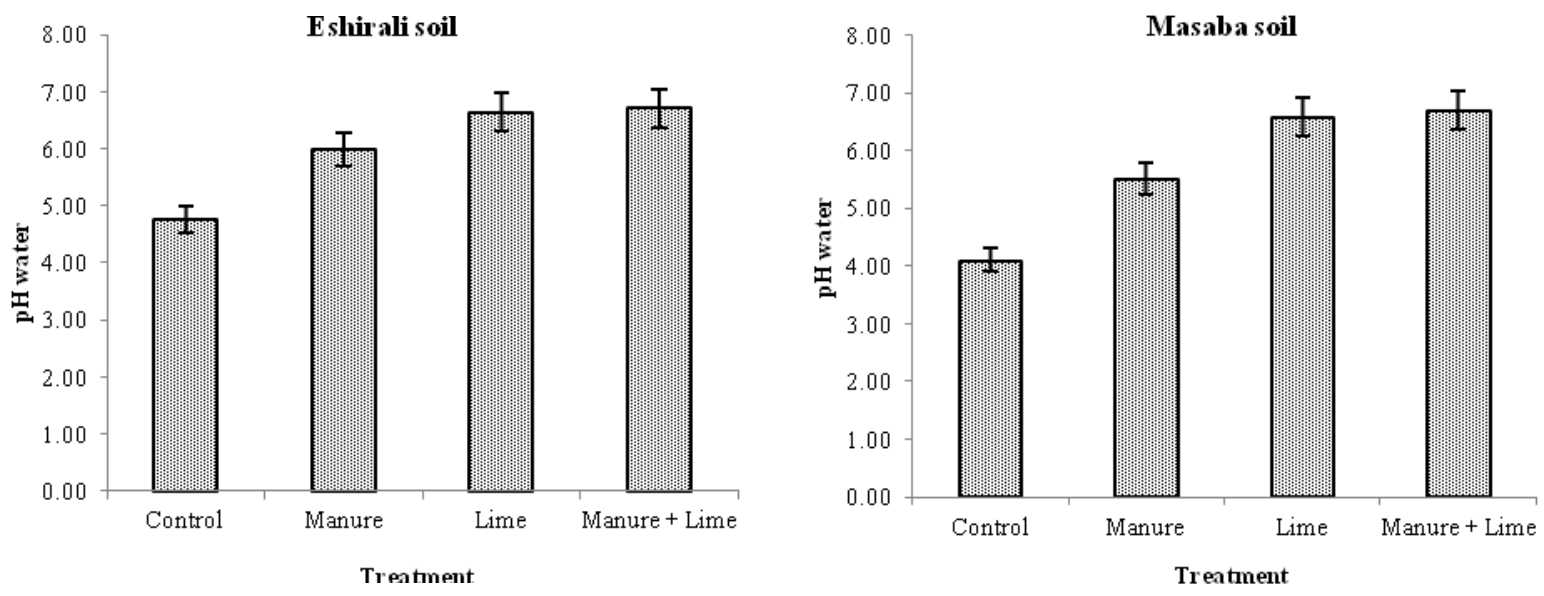

Figure 1. Illustrates the effect of manure and lime application on the soil $\mathrm{pH}$ brought from Eshirali and Masaba regions

\subsection{Effect of Inorganic Fertilizers, Manure and Lime Application on the Uptake of N, P and K Nutrients by Soybean}

Nitrogen: Nitrogen uptake was significantly influenced $(\mathrm{p}<0.001)$ by manure, lime and NPK treatments, singly and in combination (Table 1). In both soils, shoot $\mathrm{N}$ was lower at control (1.71-1.81\%), NPK (1.85-1.98\%) and manure $(2.00-2.11 \%)$ treatments than at all other treatments, except NPK+manure in Masaba soils. Manure+lime+NPK and NPK+lime treatments recorded higher shoot N (5.75-5.61\%) than most of the treatments.

Phosphorus: Phosphorus uptake was significantly influenced $(\mathrm{P}<0.001)$ by the treatments in both Eshirali and Masaba soils (Table 1). Significantly higher shoot P content $(0.51 \%$ in Eshirali and $0.54 \%$ in Masaba) was recorded under manure+lime+NPK and NPK+lime treated pots than all the other treatments. Generally, control, manure, lime, lime + manure and NPK + manure treatments were not significantly different in shoot P uptake.

Potassium: Potassium levels were significantly influenced $(p<0.001)$ by the application of inorganic fertilizers, manure and lime (Table 1). At Eshirali, control and NPK treatments recorded significantly lower shoot K levels 
than all the other treatments. Application of lime resulted in higher $\mathrm{K}$ uptake than manure application. There were no significant differences in K uptake among NPK+manure, NPK+lime and manure+lime+NPK treatments. A similar observation was made at Masaba except that lime, lime+manure, manure+lime + NPK and NPK + lime treatments recorded higher shoot $\mathrm{K}$ content than NPK+manure.

Table 1. Effect of inorganic fertilizers, manure and lime application on the uptake of N, P and K nutrients

\begin{tabular}{|c|c|c|c|c|c|c|}
\hline & \multicolumn{2}{|c|}{$\% \mathrm{~N}$} & \multicolumn{2}{|c|}{$\% \mathrm{P}$} & \multicolumn{2}{|c|}{$\% \mathrm{~K}$} \\
\hline & Eshirali & Masaba & Eshirali & Masaba & Eshirali & Masaba \\
\hline Control & 1.81 & 1.71 & 0.15 & 0.11 & 1.31 & 1.35 \\
\hline NPK & 1.98 & 1.85 & 0.15 & 0.12 & 1.39 & 1.40 \\
\hline Manure & 2.11 & 2.00 & 0.16 & 0.15 & 1.59 & 1.45 \\
\hline Lime & 3.82 & 3.94 & 0.18 & 0.22 & 2.31 & 2.65 \\
\hline Lime+manure & 4.17 & 3.96 & 0.19 & 0.31 & 2.46 & 2.68 \\
\hline NPK+manure & 4.63 & 2.70 & 0.26 & 0.19 & 2.62 & 1.54 \\
\hline NPK+lime & 5.56 & 5.51 & 0.45 & 0.45 & $2.7 \mathrm{~d}$ & 2.69 \\
\hline Manure+lime+NPK & 5.75 & 5.61 & 0.51 & 0.54 & 2.75 & 2.70 \\
\hline $\operatorname{LSD}_{(p \leq 0.05)}$ & $1.12^{* * * *}$ & $1.00^{* F^{*} x^{\prime}}$ & $0.21^{* * *_{1}}$ & $0.12^{* * * *}$ & $0.27^{* \text { *** }}$ & $0.15^{* * *}$ \\
\hline $\mathrm{CV} \%$ & 5.23 & 4.29 & 6.03 & 5.91 & 6.20 & 6.88 \\
\hline
\end{tabular}

Note. $\mathrm{N}=$ nitrogen; $\mathrm{P}=$ phosphorus; $\mathrm{K}=$ potassium; $\mathrm{CV}=$ coefficient of variation; $\mathrm{LSD}=$ least significant difference; $* * *$ significant at $\mathrm{p}<0.001$.

\subsection{Effect of Inorganic Fertilizers, Manure and Lime Application on the Growth of Soybean}

Plant height: Application of inorganic fertilizers manure and lime showed significant effect $(p<0.001)$ on plant height in Eshirali and Masaba soils (Table 2). All the treatments with manure or lime had significantly taller soybean plants than the control and NPK treatments. Application of manure and lime singly or in combination resulted in similar plant heights on Eshirali soils. In Masaba soils, there were no significant differences between NPK and manure treatments and among lime, lime+manure and NPK + manure treatments. Manure + lime $+\mathrm{NPK}$ and NPK+lime treatments produced significantly taller soybean plants than all the other treatments. However, there were no differences in heights between these two treatments.

Leaf area: Soybean leaf area was influenced $(\mathrm{p}<0.001)$ by the application of inorganic fertilizers, manure and lime in Eshirali and Masaba soils (Table 2). On both soils, control (Eshirali $=58.8 \mathrm{~cm}^{2}$ and Masaba $=49.0 \mathrm{~cm}^{2}$ ) and NPK (Eshirali $=62.1 \mathrm{~cm}^{2}$ and Masaba $=58.4 \mathrm{~cm}^{2}$ ) treatments had significantly lower leaf areas than all the other treatments. There were no significant differences between manure and lime and among manure+lime, $\mathrm{NPK}+$ manure and NPK+lime treatments in Eshirali soil. In Masaba soil, similar leaf areas were recorded among manure, lime and manure+lime and between NPK+manure and NPK+lime treatments. In all soils, manure+lime+NPK treatment recorded significantly higher leaf area (Eshirali $=184.6 \mathrm{~cm}^{2}$ and Masaba $=181.6$ $\mathrm{cm}^{2}$ ) than all other treatments.

Aboveground biomass: The treatment effect on shoot biomass was significant $(p<0.001)$ on both Eshirali and Masaba soils. Control and NPK treatments had significantly lower shoot dry weight than all the other treatments in both soils. Similar biomass weights were recorded among manure, lime, manure+lime and manure+NPK and between NPK+lime and manure+lime+NKP in Eshirali soil. In Masaba soil, similar biomass weights were recorded among soybean crops treated with manure, NPK+manure, NPK+lime and manure+lime+NPK, and among lime, manure+lime and NPK+manure treatments. 
Table 2. Effect of inorganic fertilizers, manure and lime application on soybean height, leaf area and aboveground biomass

\begin{tabular}{|c|c|c|c|c|c|c|}
\hline & \multicolumn{2}{|c|}{ Plant height $(\mathrm{cm})$} & \multicolumn{2}{|c|}{ Leaf area $\left(\mathrm{cm}^{2}\right)$} & \multicolumn{2}{|c|}{ Dry biomass (g/plant) } \\
\hline & Eshirali & Masaba & Eshirali & Masaba & Eshirali & Masaba \\
\hline Control & 24.38 & 20.25 & 58.80 & 49.00 & 3.52 & 2.72 \\
\hline NPK & 25.80 & 24.88 & 62.10 & 58.40 & 5.78 & 3.74 \\
\hline Manure & 35.25 & 30.10 & 118.10 & 117.10 & 11.29 & 8.85 \\
\hline Lime & 38.5 & 37.12 & 129.60 & 119.10 & 13.57 & 13.90 \\
\hline Manure+lime & 39.62 & 40.25 & 157.00 & 127.00 & 14.83 & 15.40 \\
\hline $\mathrm{NPK}+$ manure & 40.37 & 39.75 & 159.20 & 164.10 & 16.74 & 10.79 \\
\hline NPK+lime & 48.62 & 49.35 & 165.70 & 151.20 & 18.97 & 20.51 \\
\hline Manure+lime+NPK & 52.75 & 54.38 & 184.60 & 181.60 & 21.98 & 22.05 \\
\hline $\operatorname{LSD}_{(p \leq 0.05)}$ & $5.10^{* * * 3}$ & $6.50^{* * *}$ & $11.86^{\bar{*} \bar{*}}$ & $10.22^{* * *}$ & $5.50^{* *^{*} \bar{*}}$ & $5.00^{* * *}$ \\
\hline $\mathrm{CV} \%$ & 4.20 & 4.50 & 4.10 & 4.10 & 5.00 & 5.20 \\
\hline
\end{tabular}

Note. $* * *$ Significant at $\mathrm{p}<0.001 ; \mathrm{N}=$ nitrogen; $\mathrm{P}=$ phosphorus; $\mathrm{K}=$ potassium; $\mathrm{LSD}=$ least significant difference; $\mathrm{CV}=$ coefficient of variation.

\subsection{Relationship between Soil pH and Uptake of Nutrients and between Biomass and Uptake of Nutrient}

Positive relationship $(\mathrm{p}<0.05)$ was observed between soil $\mathrm{pH}$, soybean biomass and nutrient uptake. The relationship was between 0.30 and 0.77 for $\mathrm{pH}$ and $\mathrm{N}, \mathrm{P}$ and $\mathrm{K}$ nutrient uptake and between 0.68 and 0.99 for biomass and N, P and K nutrient uptake (Figure 2).

a) Soil $\mathrm{pH}$ versus the uptake of $\mathrm{N}, \mathrm{P}$ and $\mathrm{K}$ nutrients
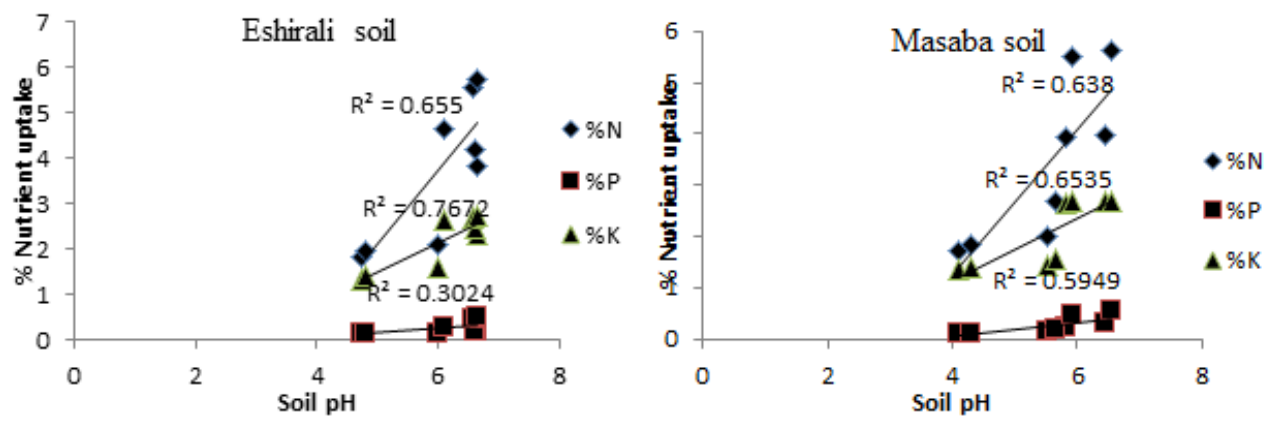

b) Biomass versus uptake of $\mathrm{N}, \mathrm{P}$ and $\mathrm{K}$ nutrients
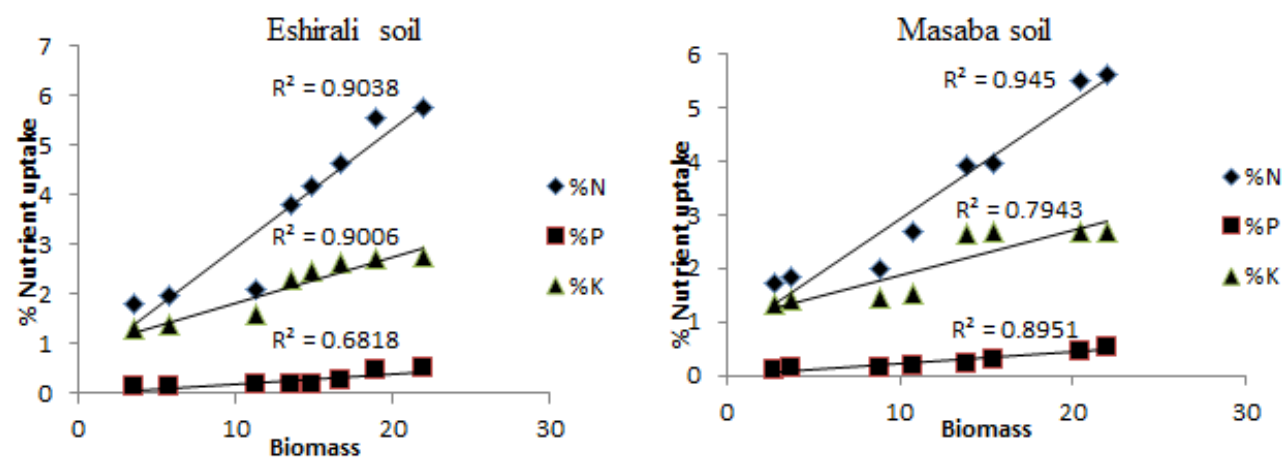

Figure 2. Relationship between soil $\mathrm{pH}$, aboveground biomass and the uptake of N, P and $\mathrm{K}$ nutrient by soybean grown in acid soils from Eshirali and Masaba regions in Western Kenya; $\mathrm{N}=$ nitrogen; $\mathrm{P}=$ phosphorus; $\mathrm{K}=$ potassium 


\subsection{Effect of Inorganic Fertilizers, Manure and Lime Application on Nodulation of Soybean}

Soybean nodulation was significantly influenced $(\mathrm{p}<0.001)$ by the application of manure, fertilizers and lime in Eshirali and Masaba soils (Figure 3). Significantly lower nodule numbers and nodule dry weights per plant were observed under control and all treatments with NPK fertilizers than all the other treatments. Similar nodule numbers and dry weights per plant were recored among NPK+manure, NPK+lime and manure+lime+NPK treatments in Masaba and Eshirali soils. The highest nodule numbers and nodule dry weights per soybean plant in both soils were recorded in pots treated with lime+manure followed by pots treated either with lime or manure.

a) Number of nodules per plant

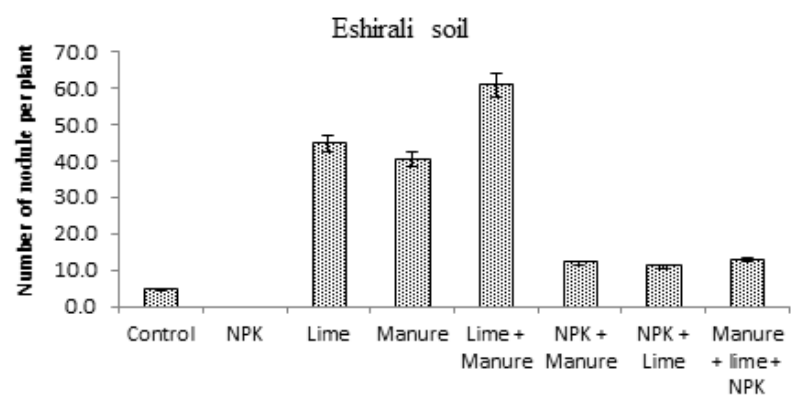

Treatments

b) Nodule dry weights in milligrams per plant

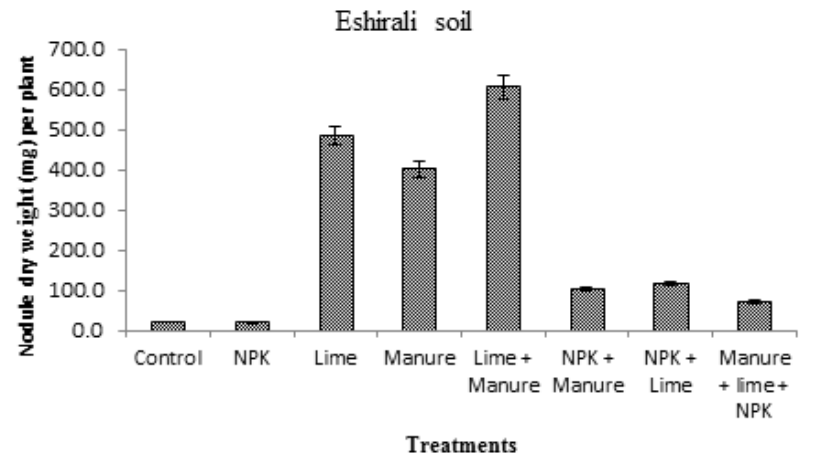

Masaba soil
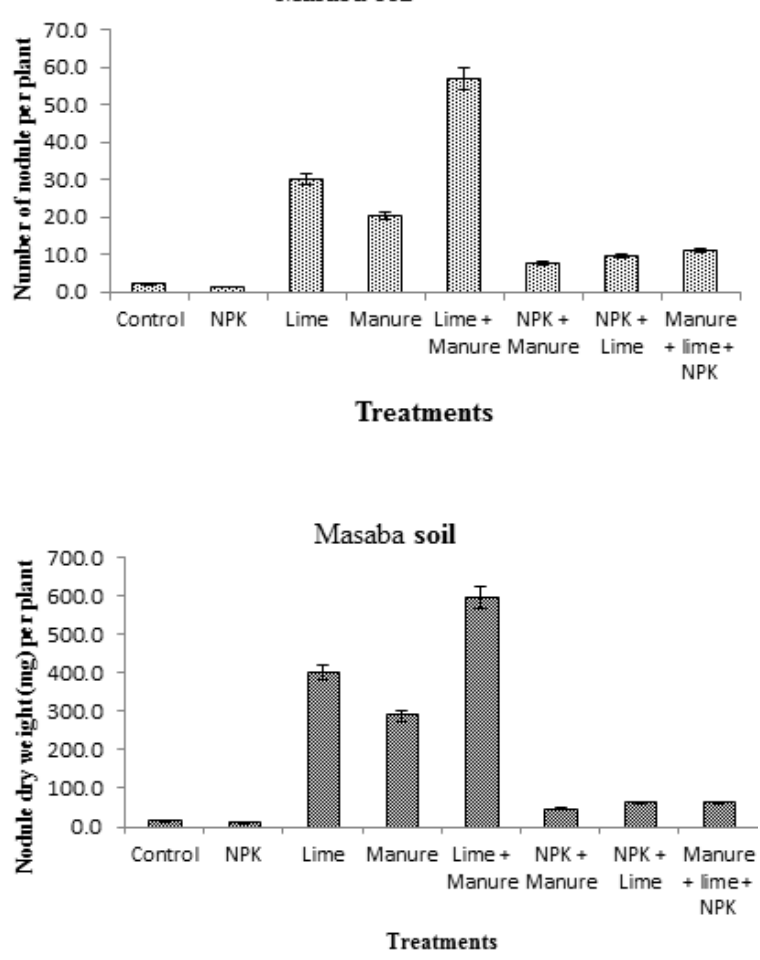

Figure 3. Effect of inorganic fertilizers, manure and lime application on the number of nodules and nodules dry weights per soybean plant; $\mathrm{N}=$ nitrogen; $\mathrm{P}=$ phosphorus; $\mathrm{K}=$ potassium

\section{Discussion}

Application of manure and lime significantly affected soil $\mathrm{pH}$ across all soils. Higher $\mathrm{pH}$ values were recorded as a result of combined application of manure with lime followed by sole application of lime. These findings are in agreement with Khoi et al. (2010), Kisinyo et al. (2012), and Verde et al. (2013a) who reported increased soil pH due to either singly or combined application of lime and manure in western and central Kenya. Application of manure alone moderately raised soil $\mathrm{pH}$ compared to lime and their combination. This decrease in soil acidity due to manure application could be due to the reduction in concentrations of aluminium, manganese and iron ions in the soil through the formation of complex compounds (Naramabuye \& Haynes, 2006; Okwuagwu et al., 2003; Onwonga et al., 2008). This complexation by manure is due to strong bonding ability of organic matter in both the solid and solution phases with aluminium (Tipping \& Woof, 1991). On the other hand, decrease in soil acidity due to the application of lime could have been due to the neutralization of hydrogen ions by hydroxyl groups to form water while calcium ions may have formed complex compounds of aluminium, manganese and iron (Kisinyo et al., 2012; Anderson et al., (2013). The combined effects of lime and manure application explain the highest $\mathrm{pH}$ values recorded under manure+lime treatments.

Low uptake of N, P and K nutrients was recorded under control, manure and NPK treatments compared to the other treatments. This could have been due to the detrimental effect of low soil pH (below pH 5 as observed in 
this study) compared to the recommended $\mathrm{pH}$ of 6 to 6.8 for soybean production (Mallavine et al., 2011). Such low $\mathrm{pH}$ hindered normal root growth, development, and absorption of water and nutrients (Lin et al., 2011). Highest uptake of N, P and K nutrients was recorded under lime+manure+NPK treatments, which was then followed by lime+NPK treatments. Kisinyo et al. (2012) also recorded high P uptake by Sesbania crop under lime application compared to control. Under this study, lime+manure+NPK treatment recorded high soil $\mathrm{pH}$ that was within the favorable range required for soybean production, hence, high uptake of $\mathrm{N}, \mathrm{P}$ and $\mathrm{K}$ nutrients. Inclusion of manure in the treatment may have also released more N, P and K nutrients for soybean uptake.

The effect of lime, manure and fertilizer application was significant on important soybean growth variables: leaf area, plant height and biomass production. Consistently small leaf area, short plants and low biomass were observed under control and NPK treatments compared to other treatments. Verde et al. (2013b) also reported shorter soybean plants due to application of inorganic fertilizer alone without any soil amendment compared to other treatments that had either lime or manure or both. The poor soybean performance observed could have been due to high soil acidity that fixed nutrients, hence, making them unavailable for plant use. Significantly higher aboveground biomass was recorded under lime+manure+NPK and NPK+lime treatments than under all other treatments. This could be due to the ameliorated soil $\mathrm{pH}$ around soybean rhizosphere that encouraged healthy root development with improved uptake of nutrients (Cifu et al., 2004). Addition of dolomitic lime and manure may have supplied extra $\mathrm{Ca}, \mathrm{Mg}$ and other nutrients that improved further soybean growth (Adeleye et al., 2010; Bambara \& Ndakidemi, 2010; Chimdi et al., 2012).

Both nodule numbers and dry weight per plant were significantly influenced by the application of manure, lime and inorganic fertilizers. Lowest nodule number and weight was recorded under control treatment. This could be due to very acidic conditions that affected rhizobia growth and development. It has been reported that such low $\mathrm{pH}$ hinders nodulation through the inhibition of the expression of rhizobia nodulation genes and reduction of Nod factor (Moron et al., 2005). This may have disrupted the exchange of signals between soybean plant root-hairs and the bacteria for formation of infection thread (Maransari et al., 2006). Low nodulation under manure+NPK, lime+NPK and manure+lime+NPK treatments could have been due to high $\mathrm{NO}_{3}{ }^{-}$(not measured in this study) made available in the soil. Effects of high $\mathrm{NO}_{3}{ }^{-}$on nodulation have also been reported by (Fujikake et al., 2002; Ferguson \& Mathesius, 2003). Although the mechanism of nitrate inhibition is not clear, several hypotheses have been used to explained the cause of inhibition of nodulation; carbohydrate-deprivation in nodules (Fujikake et al., 2003), inhibition of feedback by glutamine and asparagines (Bacanamwo \& Harper, 1997) and restriction of oxygen movement into the nodules for bacteria respiration (Gordon et al., 2002). However, high nodulation was recorded under lime, manure and lime+lime treatments. This may be due to suitable $\mathrm{pH}$ that favoured healthy root development and low nitrate both of which encouraged nodulation. Also, $\mathrm{Ca}^{2+}$ from soil and added dolomitic lime and manure may have added more calcium that created suitable conditions for $\mathrm{Ca}^{2+}$-dependent adhesions responsible for attachment of rhizobia bacteria to soybean root hairs and formation of infection thread (Smit et al., 1992).

Under such low soil $\mathrm{pH}$ in western Kenya, application of inorganic nutrient sources may not be beneficial for soybean production since the nutrients become unavailable for plant uptake. Adequate application of either lime, manure or a combination of both is therefore important in ensuring improved soil nutrient availability and soil fauna for better soybean growth and nodulation as observed under this study. The high nodulation level is associated with high $\mathrm{N}$ fixed for the crop and residuals left for subsequent crops in the cropping system.

\section{Acknowledgements}

The authors appreciate the financial support offered by International Plant Nutrition Institute (IPNI) and the technical and professional guidance offered by College of Agriculture and Veterinary Sciences, University of Nairobi.

\section{References}

Adeleye, E. O., Ayeni, L. S., \& Ojeniyi, S. O. (2010). Effect of poultry manure on soil physico-chemical properties, leaf nutrient contents and yield of yam (Dioscorea rotundata) on alfisol in southwestern Nigeria. Journal of American Science, 6(10), 871-878.

Adelodun, K. (2011). Soybean: Africa's potential Cinderella food crop. In T.-B. Ng (Ed.), Biochemistry, Chemistry and Physiology. InTech.

Anderson, N. P., Hart, J. M., Sullivan, D. M., Horneck, D. A., Pirelli, G. J., \& Christensen, N. W. (2013). Applying lime to raise soil $p H$ for crop production (Western Oregon). Corvallis, Or.: Extension Service, Oregon State University. 
Bacanamwo, M., \& Harper, J. E. (1997). The feedback mechanism of nitrate inhibition of nitrogenase activity in soybean may involve asparagines and/or products of its metabolism. Plant Physiology, 100, 371-377. https://doi.org/10.1111/j.1399-3054.1997.tb04795.x

Bambara, S., \& Ndakidemi, P. A. (2010). The potential roles of lime and molybdenum on the growth, nitrogen fixation and assimilation of metabolites in nodulated legume: A special reference to Phaseolus vulgaris L. African Journal of Biotechnology, 9(17), 2482-2489.

Bremner, J. M., \& Mulvaney, C. S. (1982). Nitrogen-Total. In A. L. Page (Ed.), Methods of Soil Analysis (Part 2). Chemical and Microbiological Properties (pp. 595-624). American Society of Agronomy, Soil Science Society of America.

Chianu, J. N., \& Vanlauwe, B. (2006). Soybean: A new role in western Kenya. Highlights CIAT in Africa (No. 35). CIAT, Kampala, Uganda.

Chianu, J. N., Vanlauwe, B., Mahasi, J. M., Katungi, E., Akech, C., Mairura, F. S., Chianu, J. N., \& Sanginga, N. (2008). Soybean situation and outlook analysis: The case of Kenya (p. 68). TSBF-CIAT, AFNET.

Chimdi, A., Gebrekidan, V., Kibret, K., \& Tadesse, A. (2012). Effects of Liming on Acidity-Related Chemical Properties of Soils of Different Land Use Systems in Western Oromia, Ethiopia. World Journal of Agricultural Sciences, 8(6), 560-567.

Cifu, M., Xiaonan, L., Zhihong, C., Zhengyi, H., \& Wanzhu, M. (2004). Long-term effects of lime application on soil acidity and crop yields on a red soil in Central Zhejiang. Plant and Soil, 265(1-2), 101-109. https://doi.org/10.1007/s11104-005-8941-y

Fatondji, D., Martius, C., Zougmore, R., Vlek, P., Bielders, C., \& Koala, S. (2009). Decomposition of organic amendment and nutrient release under the Zai technique in the Sahel. Nutrient Cycling in Agroecosystems, 85, 225-239. https://doi.org/10.1007/s10705-009-9261-z

Ferguson, B. J., \& Mathesius, U. (2003). Signaling interactions during nodule development. Journal of Plant Growth Regulator, 22, 47-72. https://doi.org/10.1007/s00344-003-0032-9

FAOSTAT (Food and Agriculture Organization of the United Nations). (2014). Soybeans production in Kenya. Retrieved from http://www.fao.org/faostat/en/\#data/QC

Fujikake, H., Yamazaki, A., Ohtake, N., Sueyoshi, K., Matsuhashi, S., Ito, T., ... Ohyama, T. (2003). Quick and reversible inhibition of soybean root nodule growth by nitrate involves a decrease in sucrose supply to nodules. Journal of Experimental Botany, 54, 1379-1388. https://doi.org/10.1093/jxb/erg147

Fujikake, H., Yashima, H., Sato, T., Ohtake, N., Sueyoshi, K., \& Ohyama, T. (2002). Rapid and reversible nitrate inhibition of nodule growth and $\mathrm{N}_{2}$ fixation activity in soybean (Glycine max (L) Merr.). Soil Science and Plant Nutrition, 48, 211-217. https://doi.org/10.1080/00380768.2002.10409193

Gordon, A. J., Skot, L., James, C. L., \& Minchin, F. R. (2002). Short-term metabolic response of soybean root nodules to nitrate. Journal of Experimental Botany, 53, 423-428. https://doi.org/10.1093/jexbot/53.368.423

Gudu, S. O., Kisinyo, P. O., Makatiani, E. T., Odee, D. W., Esegu, J. F. O., Chamshama, S. A. O., ... Owuoche, J. O. (2009). Screening of Sesbania for tolerance to aluminum toxicity and symbiotic effectiveness with acid tolerant rhizobia strains in Western Kenya acid soil. Experimental Agriculture, 45, 417-427. https://doi.org/10.1017/S0014479709990044

Haynes, R. J., \& Mokolobate, M. S. (2001). Amelioration of Al toxicity and deficiency in acid by additions of organic residues: A critical review of the phenomenon and the involved mechanisms. Nutrient Cycling in Agroecosystems, 59, 47-63. https://doi.org/10.1023/A:1009823600950

Johnson, A., \& Wood, M. (1990). DNA, a possible site of action of aluminum in Rhizobium sp. Applied and Environmental Microbiology, 263, 502-504.

Kanyanjua, S. M., Ireri, L., Wambua, S., \& Nandwa, S. M. (2002). Acidic soils in Kenya: Constraints and remedial options. KARI Technical Note (No. 11). KARI Headquarters, Nairobi, Kenya.

Khoi, C. M., Guong, V. T., Trung, P. N. M., \& Nilsson, S. I. (2010). Effects of compost and lime amendment on soil acidity and $N$ availability in acid sulfate soil (pp. 52-55). In 19th World Congress of Soil Science, Soil Solutions for a Changing World, Brisbane, Australia. 
Kisinyo, P. O., Gudu, S. O., Othieno, C. O., Okalebo, J. R., Opala, P. A., Maghanga, J. K., ... Nekesa, A. O. (2012). Effects of lime, phosphorus and rhizobia on Sesbania sesban performance in a Western Kenyan acid soil. African Journal of Agricultural Research, 7(18), 2800-2809. https://doi.org/10.5897/AJAR11.1450

Lin, M.-H., Gresshoff, P. M., \& Ferguson, B. J. (2012). Systemic Regulation of Soybean Nodulation by Acidic Growth Conditions. Plant Physiology, 160, 2028-2039. https://doi.org/10.1104/pp.112.204149

Mahasi, J. M., Vanlauwe, B., Mursoy, R. C., Mbehero, P., \& Mukalama, J. (2010). Increasing productivity of soybean in western Kenya through evaluation and farmer participatory variety selection. In L. A. Wasilwa, J. Ouda, I. W. Kariuki, N. S. Mangale, \& M. N. Lukuyu (Eds), Transforming Agriculture for Improved Livelihoods through Agricultural Product Value Chain. Proceedings of the 12th KARI Biennial Scientific Conference, November 8-12, 2010. Nairobi, Kenya.

Mallarino, A. P., Agustin, P., \& Sawyer, J. E. (2011). Corn and soybean response to soil pH level and liming (p. 93). 2011 Integrated Crop Management Conference, Iowa State University, USA.

Mbakaya, D. (2007). Annual Report for KARI Kakamega showing mean maize yields for each soil fertility demonstrated technology in Kabras. Long Rains 2007.

Miransari, M., Balakrishnan, P., Smith, D., Mackenzie, A., Bahrami, H., Malakouti, M., \& Rejali, F. (2006). Overcoming the stressful effect of low $\mathrm{pH}$ on soybean root hair curling using lipochitooligosacharides. Community of Soil Science and Plant Analysis, 37, 1103-1110. https://doi.org/10.1080/00103620600586391

Morón, B., Soria-Díaz, M. E., Ault, J., Verroios, G., Noreen, S., Rodríguez-Navarro, D. N., ... Sousa, C. (2005). Low $\mathrm{pH}$ changes the profile of nodulation factors produced by Rhizobium tropici CIAT899. Chemical Biology, 12, 1029-1040. https://doi.org/10.1016/j.chembiol.2005.06.014

Naramabuye, F. X., \& Haynes, R. J. (2006). Short-term effects of three animal manures on soil pH and Al solubility. Soil Research, 44, 515-521. https://doi.org/10.1071/SR05062

Okwuagwu, M. I., Alleh, M. E., \& Osemwota, I. O. (2003). The effects of organic and inorganic manure on soil properties and yield of okra in Nigeria. African Crop Science Conference Proceedings (Vol. 6, pp. 390-393).

Onwonga, R. N., Lelei, J. J., \& Mochoge, B. B. (2010). Mineral nitrogen and microbial biomass dynamics under different acid soil management practices for maize production. Journal of Agricultural Science, $2(1), 16$. https://doi.org/10.5539/jas.v2n1p16

Onwonga, R. N., Lelei, J. J., Freyer, B., Friedel, J. K., Mwonga, S. M., \& Wandhawa, P. (2008). Low cost technologies for enhancing $\mathrm{N}$ and $\mathrm{P}$ availability and maize (Zea mays L.) performance on acid soils. World Journal of Agricultural Sciences, 4, 862-873.

Owino, C. O., Owuor, P. O., \& Sigunga, D. O. (2015). Elucidating the causes of low phosphorus levels in ferralsols of Siaya County, Western Kenya. Journal of Soil Science and Environmental Management, 6(9), 260-267. https://doi.org/10.5897/JSSEM15. 0484

Page, A. I., Miller, R. H., \& Keeney, D. R. (1982). Method of soil analysis part 2: Chemical and mineralogical properties. Agronomy monograph (No. 9). ASA-SSSA Madison, Wisconsin.

Smit, G., Swart, S., Lugtenberg, B. J., \& Kijne, J. W. (1992). Molecular mechanisms of attachment of Rhizobium bacteria to plant roots. Molecular Microbiology, 6, 2897-2903. https://doi.org/10.1111/j.1365-2958.1992. tb01748.x

Tipping, E., \& Woof, C. (1991). The distribution of humic substances between the solid and aqueous phases of acid organic soils: A description based on heterogeneity and charge-dependent sorption equilibria. Journal of Soil Science, 42, 437-448. https://doi.org/10.1111/j.1365-2389.1991.tb00421.x

Verde, B. S., Danga, B. O., \& Mugwe, J. N. (2013b). Effects of manure, lime and mineral P fertilizer on soybean yields and soil fertility in a humic nitisol in the Central Highlands of Kenya. International journal of Agricultural Science Research, 2(9), 283-291.

Verde, B. S., Danga, B. O., \& Mugwe, J. N. (2013b). The Effects of Manure, Lime and P Fertilizer on N Uptake and Yields of Soybean (Glycine $\max$ (L.) Merrill) in the Central Highlands of Kenya. Journal of Environmental Science and Engineering, B, 2(2B), 111. 


\section{Copyrights}

Copyright for this article is retained by the author(s), with first publication rights granted to the journal.

This is an open-access article distributed under the terms and conditions of the Creative Commons Attribution license (http://creativecommons.org/licenses/by/4.0/). 